\title{
Impact of Gaseous Air Pollutants on Agricultural Crops in Developing Countries: A Review
}

\author{
SATESH KUMAR DEVRAJANI, MEHRAN QURESHI, UZMA IMRAN*, ZEESHAN \\ AHMED MEMON
}

Pakistan.

*Corresponding Authors: UZMA IMRAN, paksitan

\begin{abstract}
This review provides knowledge about air pollution and its impact on agriculture crop yield and quality in developing countries. The need of increasing agriculture production has been very important for the increasing of population. Air pollutants pose risks on yield of crops depending on the emission pattern, atmospheric transport and leaf uptake and on the plant's biochemical defence capacity. In the recent research it is identified that the agriculture production is being affected by air pollution, the impact of air pollution is caused by number of air pollutants (sulphur dioxide $\left(\mathrm{SO}_{2}\right)$, Nitrogen oxides $\left(\mathrm{NO}_{x}\right)$, and Ozone $\left(\mathrm{O}_{3}\right)$. Air pollutants produce reactive oxygen species (ROS), which adversely affect biochemical processes of plants and reduce their tolerance capacity to other stresses also. Several vital physiological processes such as photosynthetic $\mathrm{CO}_{2}$ fixation and energy metabolism are also affected negatively by air pollutants. An adverse effect caused by air pollutants depends not only upon its concentration, but also on the duration and combination of air pollutants. Ozone is the most phytotoxic of the common air pollutants. It is concluded that the continuous increasing concentration of pollutants will pose a critical threat to future world food security.
\end{abstract}

Keywords: air pollution, agriculture, $\mathrm{SO}_{2}, \mathrm{NO}_{2}, \mathrm{O}_{3}$.

\section{INTRODUCTION}

Developmental activities are the seeds of environmental damage which are necessary for the needs and greed of man. The various activities like manufacturing, processing, consumption and transportation not only depleting the stock of natural resources but also destroy the environmental system. The productivity of the economic system of the countries depends upon the supply and quality of environmental and natural resources. Air, water, soil and noise pollution are the by-products of economic development. The word pollution is derived from the Latin word 'pollutioneum' which means to make dirty. According to National Environmental Research Council, "Pollution is viewed as the release of substances and energy as waste products of human activities, which result in harmful changes within the natural environment". The concentration and duration of one or more contaminant like dust, gas, mist, odour, smoke, smog and harmful gases in the outdoor atmosphere is injurious to human beings, animal and plants life. The developed and developing countries have always aimed to minimize the constraints to the maximum production of crop yield. These constraints can also be abiotic, consisting of nutrient deficiency, metallic toxicity, salinity, low and high temperatures, wind and waterlogging. there are also numerous biotic constraints: invertebrates and vertebrates pests; fungal, viral and bacterial pathogens and trampling. The vast amount of money is being spent in order to overcome these issues and increase agriculture yield. Another constraint which is less noticeable but with the proof it is identified that the air pollution is a widespread threat to agricultural production.

Some countries are aware of the effects of air pollution on crops and they are practicing reducing the effects of air pollutants on crops and increase the yield of crops, but some countries are just striving increasing the crop yield for rapidly expanding population. Air pollution has become a serious problem and adversely affect health, vegetation, aquatic ecosystem and materials. Rapid urbanization, industrialization, and energy consumption are taking place in many developing countries with poor emission controls. The motor vehicles are growing at a high rate in the developing countries, mostly poor and old maintained vehicles that play a vital role in the deterioration of air quality. Thus, $\mathrm{SO} 2$ and NOx are increasing rapidly in developing countries. We know less about the pollutant $\mathrm{O} 3$ because in most countries very little attention has been paid. However, it is clear that the concentration of O3 in 
developing countries is phytotoxic (Chameides et al. 1994, 1999). The ozone which is component of photochemical smog was first observed around Los Angeles in the 1940s. It was noticed after the research into this new smog that this phenomenon not only had adverse effect but that the main culprit is O3. Photochemical reactions on NOx and volatile organic compounds (VOCs) produce ozone.

$\mathrm{SO} 2$ is one of the major pollutants emitted mainly from coal and fuel oil combustion, the emissions are increasing with a rapid increase in energy demand in many developing countries. In China, coal burning alone accounted for $72 \%$ of total energy consumption in 1998, causing more than half of the country's SO2 emissions (Yanjia and Kebin, 1999). China is now the leading emitter of SO2 in the world. Due to low sulphur content in the fuel the thermal powerplants, old and poorly maintained vehicles in developing countries, the road traffic is minor contributor of $\mathrm{SO} 2$.

Thermal power stations and automobiles` are also major sources of NOx emission, with nitric oxides being the primary pollutant but oxidized to $\mathrm{NO} 2$. NOx is predicted in the developing countries to cause widespread increases in $\mathrm{O} 3$ levels. In the table 1, it is shown the concentration of exposure and effects of the pollutants on plants indicates that what kind of problems occurs in plants with this.

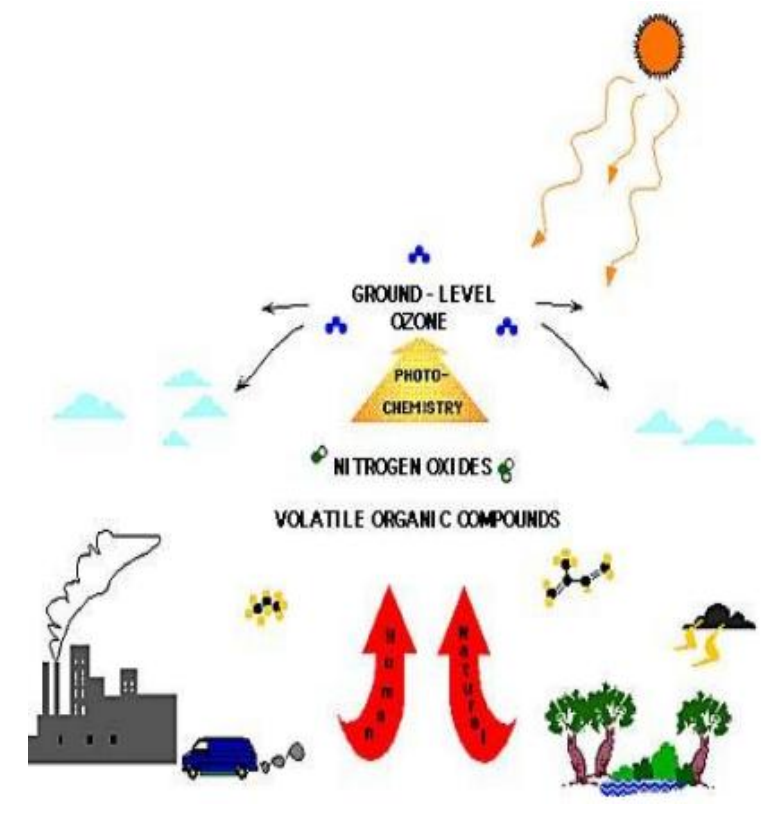

Ground-level ozone causes more damage to plants than all other air pollutants combined. Ozone is formed in the troposphere when sunlight causes complex photochemical reactions involving nitrogen oxides (NOx), volatile organic hydrocarbons (VOC) and carbon monoxide that mainly from gasoline engines and other fossil fuels combustion. Woody vegetation is another major source of VOCs. NOx and VOCs can be transported long distances by regional weather patterns before they react to create ozone in the atmosphere, where it can persist for several weeks. Through a complex series of photochemical reactions involving both NOx and volatile organic compounds (VOCs), ozone levels can be elevated above the natural background of about $40 \mathrm{ppb}$. Motor vehicles, particularly inefficient and poorly tuned engines characteristic of developing countries, are the major source of VOCs. In addition, ozone production is encouraged by the high temperatures and high light intensity characteristics of many developing country cites. Although the precursors for ozone are produced in cities, the levels of this secondary pollutant are often higher on the outskirts of the city, due to local destruction by NO at ground level within the city (UK PORG, 1993). Ozone is a cause for concern because elevated ozone levels can be widespread over rural agricultural areas, particularly downwind of cities (UK PORG, 1993). There have been very little coordinated ozone monitoring levels in rural areas of developing countries, but the limited data available are consistent with this, indicating phytotoxic levels in several important agricultural areas (Ashmore and Marshall, 1999).

Table1. Effects of air pollutants on vegetation

\begin{tabular}{|l|l|l|}
\hline Pollutant & Level (ppm) and exposure & Effects \\
\hline SO2 & $\bullet \quad 0.3$ to 0.5 for several days & $\begin{array}{l}\bullet \text { Bleached spots, Chlorosis, } \\
\text { Chronic injury to Spinach and other } \\
\text { leafy vegetables }\end{array}$ \\
\hline
\end{tabular}




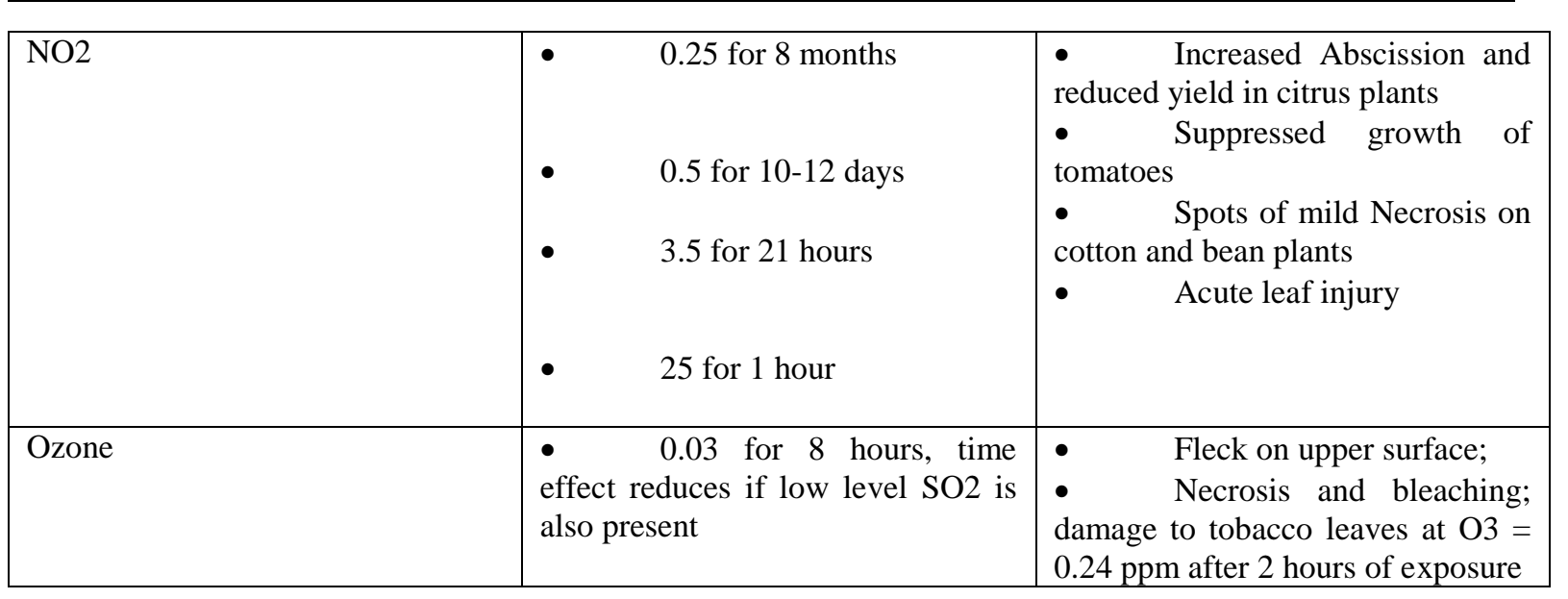

Diffusion which is governed by micro-meteorological conditions (radiation, temperature, wind, etc.) transfers gaseous atmospheric compounds from the atmosphere to plant canopies. Penetration of gases through plant is generally of minor importance (Lendzian and Kerstiens, 1991), although some pollutants such as $\mathrm{SO} 2$ can affect the plants and gain entry into the internal leaf tissue to some extent (Wellburn, 1994). Aerosols and sedimenting particles containing nutrients and pollutants (e.g., heavy metals) are deposited directly on plant surfaces or on soil surfaces; matter deposited on plant surfaces indirectly can be transmitted indirectly to the soil by run-off or by plant debris or litter.

For agriculture, persistent effects of air pollutants such as $\mathrm{O} 3$ are of particular concern, because they are due to exposures for weeks, months, or over the entire crop's lifecycle. It is well known that increasing levels of $\mathrm{O} 3$ cause a decrease in the yield of many crop species, such as wheat, rice, soybean and cotton (Ashmore, 2005).

Considering the information that urban pollution can pose a serious threat to agricultural productivity in areas around urban centers and there exist variations in pattern of pollutants due to interactions during transport.

\section{Trends in Air Pollutant -- CONCENTrations AND Distributions}

Increasing energy demands associated with economic growth and industrialization in Asia, Africa and Latin America have resulted in dramatic increases in air pollution emissions. Problems are exacerbated by rapid and poorly planned industrial growth in developing countries, the close proximity of industrial complexes and thermal power plants to residential areas (Singh, 1995) and the fact that regulation air pollution control in developing countries is often insufficient for technical and economic reasons. Air pollution kills more than 2.7 million people each year, with over $90 \%$ of these deaths in developing countries and two-thirds of them in Asia (UNDP, 1998). Thus, it is not surprising that most attention to date has concentrated on the direct impact of these industrial and urban emissions on human health. Nonetheless, very little is known about pollutant concentrations in many suburban and rural areas, whereas through decreased crop yields, food quality and income there may be significant indirect impacts of air pollution on human health.

One of the major phytotoxic primary pollutants, sulphur dioxide is emitted mainly from the coal and fuel oil combustion, with increased emissions associated with the rapidly increasing energy demands in many developing countries. For example, Asian energy demand doubles every 12 years, and burning fossil fuels, mainly coal meets $80 \%$ of demand (van Aardenneet al. 1999). As a result, SO2 emission in Asia is predicted to increase from 34 x 106tonnes in 1990 to 110 x 106tonnes by 2020 (van Aardenneet al. 1999). In China, coal burning alone accounted for 72 percent of total energy consumption in 1998, causing more than half of the country's SO2 emissions (Yanjia and Kebin, 1999). China is now the leading emitter of SO2 in the world. Coal-based power generation has also greatly increased in India over the last decade and now accounts for 64 percent of electricity generation (Agrawal and Singh, 2000). Smelters are another important, but more localized source of sulphur dioxide.

Traffic also plays an important in NOx emissions, with nitric oxide as the principal primary pollutant but being rapidly oxidized to NO2. All combustion processes at high temperatures produce NOx emissions, with thermal power plants being the other main source. A global increase in NOx emissions from 40 x 106tonnes in the mid-1980s to 55-66 x 106tonnes per year by 2025 has been predicted (Lee et al. 1997), with substantially higher percentage increases in some developing countries, such as China. 
It is anticipated that these increases in NOx will lead to large increases in $\mathrm{O} 3$ levels in developing countries.

Ozone levels can be about $40 \mathrm{ppb}$ above natural background due to a series of complex photochemical reactions involving both NOx and volatile organic compounds (VOCs). The main source of VOC is automobiles, especially ineffective and faulty tin engines, characteristic of developing countries. In addition, significant temperatures and high light intensities support ozone generation in many cities in developing countries. Although the precursors for ozone are produced in cities, the levels of this secondary pollutant are often higher on the outskirts of the city, due to local destruction by NO at ground level within the city (UK PORG, 1993). Ozone is a significant cause of concern because ozone levels can be high in rural areas of agriculture, especially in the lower cities. (UK PORG, 1993). There is little integrated monitoring of ozone levels in the rural areas of developing countries, but available data are in accordance with this, indicating phytotoxic levels in many important agricultural areas. (Ashmore and Marshall, 1999).

\section{Agriculture in the Developing Countries}

While in developing countries, in particular, the effects of air pollution on ozone have been observed. Here is the social and economic importance of the impact of air pollution on agriculture can be enormous to maintain leading food security and exchange on the importance of national agricultural production. However, the fight against air pollution is usually discussed due to limited resources and a general desire to promote industrial development.

\section{Impacts of Air Pollution On Agricultural Crops in Developing Countries}

\subsection{Ozone}

Direct effects of $\mathrm{O} 3$ on crop yields have been studied in Pakistan and India (Table 2,3,4). These studies include the use of leaf antioxidants. Chamber filtration systems are more expensive and easier to use this way.

Wahid et al. (2001) conducted an experiment in Pakistan. Here, the protective effect of EDU against soybeans (Glycine max) was assessed during the growing rainy season in suburban areas, remote rural areas and rural road areas around Lahore. Seed weight of untreated plants decreased by 53 percent, 65 percent and 74 percent at remote suburban, rural and rural road locations compared to untreated plants. The concentration of oxidants is also high in rural areas. The results suggest that ozone can have a significant impact on crop production in Pakistan, which is a major agricultural area of Pakistan (Table 4).

Table2. Describing the data collated about wheat yield response to ozone

\begin{tabular}{|c|c|c|c|c|c|c|}
\hline Reference & Study site & $\begin{array}{l}\text { Experimental type } \\
\text { (growth period) }- \\
\text { field/pot }-\mathrm{O}_{3} \\
\text { monitoring method }\end{array}$ & $\begin{array}{l}\text { Cultivator (No. } \\
\text { of data points) }\end{array}$ & $\begin{array}{l}\mathrm{SO}_{2} \text { and } \\
\mathrm{NO}_{2} \text { concs. } \\
(\mathrm{ppb})\end{array}$ & $\begin{array}{l}\mathrm{O}_{3} \quad \text { concs. } \\
(\mathrm{ppb}) \\
\text { averaging } \\
\text { period }\end{array}$ & $\begin{array}{l}\text { Yield response } \\
\text { (parameter, rel. } \\
\text { yield\%) }\end{array}$ \\
\hline Agarwal (2005) & $\begin{array}{l}\text { India, } \\
\text { Varanasi }\end{array}$ & $\begin{array}{l}\text { Fu (Dec-March) - } \\
\text { field - wet chemistry }\end{array}$ & $\begin{array}{l}\text { Winter wheat: } \\
\text { Malviya } 234 \\
\text { (2). HP1209 (2) }\end{array}$ & - & $\begin{array}{l}70 ; 100: 4-h \\
\text { mean }\end{array}$ & $\begin{array}{l}\text { Yield plant- }{ }^{1} \\
(95 \%-83 \%)\end{array}$ \\
\hline $\begin{array}{l}\text { Ambasht and } \\
\text { Agarwal (2003) }\end{array}$ & $\begin{array}{l}\text { India, } \\
\text { Varanasi }\end{array}$ & $\begin{array}{l}\mathrm{Fu} \text { (Nov-April) - } \\
\text { field - wet chemistry }\end{array}$ & $\begin{array}{lr}\text { Winter } & \text { wheat: } \\
\text { Malviya } & 234 \\
\text { (1). } & \\
\end{array}$ & - & 70; 4-h mean & $\begin{array}{l}\text { Yield } \quad \text { plant- }{ }^{1} \\
(91 \%)\end{array}$ \\
\hline Rai et al. (2007) & $\begin{array}{l}\text { India, } \\
\text { Varanasi }\end{array}$ & $\begin{array}{l}\text { Fi (Dec-March) }- \\
\text { field }- \text { UV } \\
\text { absorption }\end{array}$ & $\begin{array}{lr}\text { Winter } & \text { wheat: } \\
\text { Malviya } & 234 \\
\text { (1). } & \end{array}$ & $\begin{array}{l}\mathrm{SO}_{2} \quad 8, \quad 4 \\
\mathrm{NO}_{2} 39.9\end{array}$ & 40; 8-h mean & $\begin{array}{l}\text { Yield } \quad \text { plant- }{ }^{1} \\
(79 \%)\end{array}$ \\
\hline Tiwari et al. (2005) & $\begin{array}{l}\text { India, } \\
\text { Varanasi }\end{array}$ & $\begin{array}{l}\text { EDU (300 ppm) } \\
\text { (Dec-March) - field } \\
\text { - UV absorption }\end{array}$ & $\begin{array}{l}\text { Winter wheat: } \\
\text { Malviya } 533 \\
(1) \text { Malviya } \\
234 \text { (1) }\end{array}$ & - & 41; 8-h mean & $\begin{array}{l}\text { Yield } \\
(87 \%-81)\end{array}$ \\
\hline Wahid (2006) & $\begin{array}{l}\text { Pakistan } \\
\text { Lahore }\end{array}$ & $\begin{array}{l}\text { Fi (Dec-March) - pot } \\
\text { - UV absorption }\end{array}$ & $\begin{array}{l}\text { Spring wheat: } \\
\text { Inqlab - 91 (1). } \\
\text { Punjab-96 (1). } \\
\text { Pasban-90 (1) }\end{array}$ & $\begin{array}{l}\mathrm{SO}_{2} \\
\mathrm{NO}_{2} 30\end{array}$ & 72; 8-h mean & $\begin{array}{l}\text { Yield plant- }{ }^{1} \\
(82 \%-57 \%)\end{array}$ \\
\hline $\begin{array}{l}\text { Wahid and Maggs } \\
\text { (1999) }\end{array}$ & $\begin{array}{l}\text { Pakistan } \\
\text { Lahore }\end{array}$ & $\begin{array}{l}\text { Fi (Dec-March) - } \\
\text { field - wet chemistry }\end{array}$ & $\begin{array}{l}\text { spring wheat: } \\
\text { Rawal-87 (1). } \\
\text { Punjab-85 (1) }\end{array}$ & No data & 70; 8-h mean & $\begin{array}{l}\text { Yield plant- }{ }^{1} \\
(64 \%-52 \%)\end{array}$ \\
\hline
\end{tabular}

Fu: Fumigation; Fi: Filtration; EDU: Ethylenediurea 
Table3. Describing the data collated about rice yield response to ozone

\begin{tabular}{|c|c|c|c|c|c|c|}
\hline Reference & Study site & $\begin{array}{l}\text { Experimental } \\
\text { type (growth } \\
\text { period) } \\
\text { field/pot }-\mathrm{O}_{3} \\
\text { monitoring } \\
\text { method }\end{array}$ & $\begin{array}{l}\text { Cultivator } \\
\text { (No. of data } \\
\text { points) }\end{array}$ & $\begin{array}{l}\mathrm{SO}_{2} \text { and } \\
\mathrm{NO}_{2} \\
\text { concs. } \\
\text { (ppb) }\end{array}$ & $\begin{array}{l}\mathrm{O}_{3} \text { concs. } \\
(\mathrm{ppb}) \\
\text { averaging } \\
\text { period }\end{array}$ & $\begin{array}{l}\text { Yield } \\
\text { response } \\
\text { (parameter, } \\
\text { rel. yield\%) }\end{array}$ \\
\hline $\begin{array}{l}\text { Maggs et al. } \\
(1995)\end{array}$ & $\begin{array}{l}\text { Pakistan } \\
\text { Lahore }\end{array}$ & $\begin{array}{l}\text { Fu (May/June to } \\
\text { Oct/Nov) - pot - } \\
\text { wet chemistry }\end{array}$ & $\begin{array}{l}\text { Basmati } 385 \\
\text { (1). IRRI } 6 \\
\text { (1) }\end{array}$ & $\begin{array}{ll}\mathrm{SO} 2 & \text { no } \\
\text { data; } & \\
\mathrm{NO} 2 & \\
22.5 & \end{array}$ & $\begin{array}{l}60 ; \quad 6-h \\
\text { mean of } 3 \\
\text { days/week }\end{array}$ & $\begin{array}{l}\text { Yield plant-1 } \\
(63 \%-53 \%)\end{array}$ \\
\hline $\begin{array}{l}\text { Wahid et al. } \\
(1995)\end{array}$ & $\begin{array}{l}\text { Pakistan } \\
\text { Lahore }\end{array}$ & $\begin{array}{l}\text { Fi (July-Nov) - } \\
\text { pot - wet } \\
\text { chemistry }\end{array}$ & $\begin{array}{l}\text { Basmati } 385 \\
\text { (1). IRRI } 6 \\
\text { (1) }\end{array}$ & $\begin{array}{ll}\mathrm{SO} 2 & \text { no } \\
\text { data; } & \\
\mathrm{NO} 2 & \\
12.6 & \end{array}$ & $\begin{array}{l}36 ; \quad 6-\mathrm{h} \\
\text { mean of } 3 \\
\text { days/week }\end{array}$ & $\begin{array}{l}\text { Yield plant- }{ }^{1} \\
(63 \%-58 \%)\end{array}$ \\
\hline $\begin{array}{l}\text { Wahid et al. } \\
(1997)\end{array}$ & $\begin{array}{l}\text { Pakistan } \\
\text { Lahore }\end{array}$ & $\begin{array}{l}\text { Fi (July-Nov) - } \\
\text { pot - wet } \\
\text { chemistry }\end{array}$ & $\begin{array}{l}\text { Basmati } 370 \\
\text { (1). Basmati } \\
\text { Pak (1) }\end{array}$ & No data & $\begin{array}{l}57 ; \\
\text { mean }\end{array}$ & $\begin{array}{l}\text { Yield plant-1 } \\
(71 \%-55 \%)\end{array}$ \\
\hline
\end{tabular}

Fu: Fumigation; Fi: Filtration

Table4. Describing the data collated about various legumes yield response to ozone

\begin{tabular}{|c|c|c|c|c|c|c|}
\hline Reference & Study site & $\begin{array}{c}\text { Experimental } \\
\text { type (growth } \\
\text { period) - } \\
\text { field/pot }-\mathrm{O}_{3} \\
\text { monitoring } \\
\text { method }\end{array}$ & $\begin{array}{l}\text { Species and } \\
\text { cultivator } \\
\text { (No. of data } \\
\text { points) }\end{array}$ & $\begin{array}{c}\text { Control } \\
\text { treatment }\end{array}$ & $\begin{array}{l}\mathrm{O}_{3} \text { concs. } \\
(\mathrm{ppb}) \\
\text { averaging } \\
\text { period }\end{array}$ & $\begin{array}{c}\text { Yield } \\
\text { response } \\
\text { (parameter, } \\
\text { rel. yield\%) }\end{array}$ \\
\hline $\begin{array}{l}\text { Agarwal } \\
(2005)\end{array}$ & $\begin{array}{l}\text { India, } \\
\text { Allahabad }\end{array}$ & $\begin{array}{l}\text { Fu (July-Oct) - } \\
\text { field - wet } \\
\text { chemistry }\end{array}$ & $\begin{array}{l}\text { Soybean: } \\
\text { PK472 (2) } \\
\text { Bragg (2) }\end{array}$ & - & $\begin{array}{l}70 ; 100: 4-h \\
\text { mean }\end{array}$ & $\begin{array}{l}\text { Yield plant-1 }^{1} \\
(95 \%-66 \%)\end{array}$ \\
\hline $\begin{array}{l}\text { Agarwal et al. } \\
(2005)\end{array}$ & $\begin{array}{l}\text { India, } \\
\text { Varanasi }\end{array}$ & $\begin{array}{l}\text { EDU }(500 \text { ppm) } \\
\text { (July-Sept) - } \\
\text { field - wet } \\
\text { chemistry }\end{array}$ & $\begin{array}{l}\text { Mungbean: } \\
\text { Malviya } \\
\text { Jyoti (1). }\end{array}$ & - & $\begin{array}{l}33 ; 8-\mathrm{h} \\
\text { mean of } 1 \\
\text { day/week }\end{array}$ & $\begin{array}{l}\text { Yield plant-1 } \\
70 \%\end{array}$ \\
\hline $\begin{array}{l}\text { Ambasht and } \\
\text { Agarwal } \\
(2003)\end{array}$ & $\begin{array}{l}\text { India, } \\
\text { Varanasi }\end{array}$ & $\begin{array}{l}\text { Fu (Nov-March) } \\
\text { - field - wet } \\
\text { chemistry }\end{array}$ & $\begin{array}{l}\text { Soybean: } \\
\text { Punjab } 1 \\
\text { (1). }\end{array}$ & - & $\begin{array}{l}70 ; 4-h \\
\text { mean }\end{array}$ & $\begin{array}{l}\text { Yield plant-1 } \\
89 \%\end{array}$ \\
\hline $\begin{array}{l}\text { Bajwa et al. } \\
\text { (1997) }\end{array}$ & $\begin{array}{l}\text { Pakistan, } \\
\text { Lahore }\end{array}$ & $\begin{array}{l}\text { Fi (March-June) } \\
\text { - pot - wet } \\
\text { chemistry }\end{array}$ & $\begin{array}{l}\text { Mungbean } \\
\text { M-28 (1) }\end{array}$ & No data & $\begin{array}{l}61 ; 8-\mathrm{h} \\
\text { mean }\end{array}$ & $\begin{array}{l}\text { Yield plant-1 } \\
50 \%\end{array}$ \\
\hline $\begin{array}{l}\text { Wahid et al. } \\
(2001)\end{array}$ & $\begin{array}{l}\text { Pakistan } \\
\text { Lahore }\end{array}$ & $\begin{array}{l}\text { EDU (400 ppm) } \\
\text { (Aug-Oct and } \\
\text { Feb-May) - pot } \\
\text { - wet chemistry }\end{array}$ & $\begin{array}{l}\text { Soybean } \\
\text { NARC-1 (4) }\end{array}$ & - & $\begin{array}{l}40-75 ; 6-h \\
\text { mean }\end{array}$ & $\begin{array}{l}\text { Yield plant-1 } \\
(68 \%-35 \%)\end{array}$ \\
\hline Ahmed (2007) & $\begin{array}{l}\text { Pakistan } \\
\text { Lahore }\end{array}$ & $\begin{array}{l}\text { OTCs (March- } \\
\text { June) - pot - } \\
\text { wet chemistry }\end{array}$ & $\begin{array}{l}\text { Mungbean } \\
\text { NM-92 and } \\
\text { NM-51 (2) }\end{array}$ & - & $\begin{array}{l}62 ; 8-h \\
\text { mean }\end{array}$ & $\begin{array}{l}\text { Yield plant-1 } \\
55 \%\end{array}$ \\
\hline
\end{tabular}

Fu: Fumigation; Fi: Filtration; EDU: Ethylenediurea

Very limited open-top filtration studies have been conducted in developing countries. The most important series of experiments was again conducted in the outskirts of Lahore, Pakistan, in which two local crops of winter wheat, rice and mung beans were used for two consecutive years (Magsat al. 1995; Waheed) et al. 1995a, b; Ahmed, 2007) (Table 1,2,3). The grains were grown in open top chambers, they were aerated by air or coal filtered air, and they were subjected to local planting methods. In all four experiments, partial air treatment significantly reduced production compared to filtering air, which varied from 34 to 46 percent. The concentration of sulfur dioxide in this area was very low, but a series of fumigation studies were performed in the chamber to estimate the contribution of ozone and nitrogen dioxide to the observed decrease in production (Maggs, 1996). These studies showed that the use of a single cultivar did not show 
an effect associated with $\mathrm{NO} 2$ or $\mathrm{O} 3$, and that the reduction in yields recorded in Lahore was only related to O3. Subsequent studies using EDUs containing soy confirmed these results (Wahid et al. 2001).

\subsection{Sulphur Dioxide}

Several chamber and field studies were carried out to investigate the impact of sulfur dioxide on growing crops, especially in India. Wheat, which seems to be particularly susceptible to other major crop plants, has been studied a lot. However, most of these studies cover chamber fog with an unusually large number of SO2s, with a limited number of smokes using pollution levels. Field trials are often studied with prospective resources that are widely adopted in developed countries due to the complex and expensive nature of open-air smoking systems. In these communication studies, plant material is usually grown on standard soils and vessels and exposed to all or part of the growing season on the contaminated slope. The results can be complicated by the presence of other pollutants, especially NOx. A main study by Transect was by Shin et al. (1990) Local wheat was grown in a coalfired power plant in Uttar Pradesh, India.

Despite evidence of increased $\mathrm{SO} 2$ emissions in developing countries, empirical data show that phytotoxic effects in agriculture mostly identify sources and affect the area closest to industrial companies in those areas. Will In rural areas, however, this ignores the problem of urban and suburban agriculture, which in many places is exposed to high levels of SO2 and other pollution. Cities and urban agriculture, which are often overlooked by decision makers and planners, play a vital role in developing countries to rapidly feed the urban population. There is evidence of this. It is essential for the nutrition of the urban poor (UNDP, 1996).

\subsection{Nitrogen Dioxide}

There is little research on the impact of nitrogen dioxide on agricultural production in developing countries. Although the study by Magazine et al. (1995) indicated that NOx had no environmental impact on wheat and rice production in the suburbs of Lahore, which may be significant in urban and adjoining areas. The above study also examined the effects of NOx, which studied the effects of $\mathrm{SO} 2$ on four crops in Delhi and Varanasi. In winter, wheat yield was significantly negatively correlated ( $p<0.05$ ) with NO2 concentrations ranging from 31 to $105 \mu \mathrm{g} \mathrm{m}-3$ (Marshall et al. 1997). In Delhi the yields of both mustard and wheat were negatively correlated with NO, which ranged from 79 and 197 $\mu \mathrm{g} \mathrm{m}-3$ (Marshall et al. 1997). The transect study in Varanasi also raised the possibility that urban air pollution was having an impact on the nutritional quality, in addition to the yield of crops. The results showed significant negative relationships with $\mathrm{SO} 2$ and $\mathrm{NO} 2$ for carbohydrate and energy content, as well as for beans and wheat (Table 1).

\section{CONCLUSION}

This paper summarize that the air pollution concentrations are high enough to cause adverse impacts to crops. The continuous increasing concentration of pollutants will pose a critical threat to future world food security.

Developing countries such as India, Pakistan, and China use low quality of fuel in Powerplants and in automobiles that tend to the emit $\mathrm{SO} 2, \mathrm{NO} 2, \mathrm{O} 3$ and Particulate matters in the atmosphere that have both direct and indirect effects on humans, plants and animals.

The limited field experimental data described above clearly indicate that there may be significant crop losses in a number of important agricultural areas in the developing countries, with ozone the main cause for concern. However, this issue is little recognized and resources available to investigate it are limited. Therefore, in order to target further research efforts, it is important to be able to identify and illustrate geographical areas where there is a high risk of major crop losses. Due to various forms of air pollutants in developing countries, the proper work could have been done in detecting crop diseases.

\section{REFERENCES}

[1] Agrawal, M. (2005). Effects of air pollution on agriculture: an issue of national concern. Nation Academy Science letters - India, 28(3-4): 93-106.

[2] Agrawal, M. and J. Singh (2000). Impact of coal power plant emissions of foliar elemental concentrations in plants in a low rainfall tropical region. Environmental Monitoring and Assessment, 60: 261-282.

[3] Agrawal, S.B., A. Singh and B. Rathore (2005). Role of ethylene diurea (EDU) in assessing impact of ozone on Vignaradiata L. plants in a suburban area of Allahabad (India). Chemosphere, 61: 218-228. 
[4] Ahmed, S. (2007). The growth and development of Vignaradiatain filtered and unfiltered open topchambers. International J. Agriculture and Biology 1560-8530/2007/09-5-688-692.

[5] Ambasht, N.K. and M. Agrawal (2003a). Effects of enhanced UV-B radiation and tropospheric ozone on physiological and biochemical characteristics of field grown wheat plant. BiologiaPlantarum, 47(4): 625628.

[6] Ambasht, N.K. and M. Agrawal(2003b). Interactive effects of ozone and ultraviolet-B singly and in combination on physiological and biochemical characteristics of soybean plants. J. Plant Biology, 30(1): 37-45.

[7] Ashmore, M.R. and F.M. Marshall (1999). Ozone impacts on agriculture: an issue of global concern. Advances in Botanical Research, 29: 32-52.

[8] Bajwa, R., S. Ahmad, M. Uzma, G. Nasim and A. Wahid (1997). Impact of air pollution on mungbean (Vignaradiata) grown in OTCs in Pakistan - I. Effects on vegetative growth and yield. Scientific Khyber, 10(2):37-50.

[9] Chameides, W.L., P.S. Kasibhatla, J. Yienger and H. Levy (1994). Growth of continental scale metroagroplexes, regional ozone pollution and world food production. Science,264: 74- 77.

[10] Chameides, W.L., X. Li, X. Tang, X. Zhou, C. Luo, C.S. Kiang, J. St. John, R.D. Saylor, S.C. Liu, K.S. Lam, T. Wang and F. Giorgi (1999). Is ozone pollution affecting crop yields in China? Geophysical Research Letters, 26: 867 -870.

[11] Lee, D.S., I. Kohler, E. Grobler, F. Rohrer, K. Sausen, L. Gallardo-Klenner, J.G.J. Olivier, F.J. Dentener and A.F. Bowman (1997). Estimations of global NOx emissions and their uncertainties. Atmospheric Environment,31: 1735-1749.

[12] Maggs, R. (1996). The Effects of Ozone and Nitrogen Dioxide on Pakistan Wheat (Triticumaestivum) and Rice (Oryza sativa) Cultivars. PhD Thesis, University of London.

[13] Maggs, R., A. Wahid, S.R.A. Shamsi and M.R. Ashmore (1995). Effects of ambient air pollution on wheat and rice yield in Pakistan. Water, Air and Soil Pollution, 85: 1311-1316.

[14] Marshall, F. M., M. R. Ashmore and F. Hinchcliffe (1997). A Hidden Threat to Food Production: Air Pollution and Agriculture in the Developing World. Gatekeeper Series No. SA 73. International Institute for Environment and Development, London.

[15] Rai, R., M. Agrawal, and S.B. Agrawal, (2007). Assessment of yield losses in tropical wheat using open top chambers. Atmospheric Environment, 41: 9543-9554.

[16] Singh, O. N. (1995). Local air pollution in India. Pure and Applied Chemistry67: 1462-1465. Singh, J.S., Singh, K.P. and Agrawal, M. (1990). Environmental Degradation of Obra-RenukootSingrauli Areas and its Impact on Natural and Derived Ecosystems. Project report submitted to Ministry of Environment and Forests, Government of India, 4/167/84/MAB/EN -2RE.

[17] Tiwari, S., M. Agrawal, and W.J. Manning, (2005). Assessing the impact of ambient ozone on growth and productivity of two cultivars of wheat in India using three rates of application of ethylenediurea (EDU). Environmental Pollution, 138(1): 153-160.

[18] UK PORG (1993). Ozone in the United Kingdom 1993. United Kingdom Photoxidant Review Group, 3rd Report. Department of the Environment, London.

[19] UNDP (1996). Urban Agriculture: Food, Jobs and Sustainable Cities. United Nations Development Program, New York.

[20] UNDP (1998). Human Development Report 1998. Unite Nations Development Program. Oxford University Press, New York.

[21] Van Aardenne, J.A., G.R. Carmichael, Levy, H, D. Streets, and L. Hordijk (1999). Anthropogenic NOx emissions in Asia in the period 1990- 2020.Atmospheric Environment, 33: 633-646.

[22] Wahid. A (2006). Influence of atmospheric pollutants on agriculture in developing countries: A case study with three new wheat varieties in Pakistan. Science of the Total Environment 371: 304313.

[23] Wahid, A., and R. Maggs (1999). The effects of air pollution on crops in developing countries - a case study in Pakistan. ActaScientia, 9(2): 51-63.

[24] Wahid, A., S. R. A. Shamsi, J. N. B. Bell and M. R. Ashmore (1997). Effects of ambient air pollution on the yield of some rice varieties grown in open-top chambers in Lahore, Pakistan. ActaScientia, 7(2): 141-152.

[25] Wahid, A., R. Maggs, S.R.A. Shamsi, J.N.B. Bell, and M.R. Ashmore, (1995). Air pollution and its impact on wheat yield in the Pakistan Punjab. Environmental Pollution, 88: 147-154. 
[26] Wahid, A., R. Maggs, S. R. A. Shamsi, J. N. B. Bell and M.R. Ashmore, (1995b). Effects of air pollution on rice yield in the Pakistan Punjab. Environmental Pollution, 90: 323-329.

[27] Wahid, A., S.R.A. Shamsi, E. Milne, F.M. Marshall, F.M. and M.R. Ashmore, (2001). Effects of oxidants on soybean growth and yield in the Pakistan Punjab. Environmental Pollution, 113: 271-280.

[28] Yanjia, W. and H. Kebin (1999). The air pollution picture in China. IEEE Spectrum 36(12): 55-58.

[29] Adams, R.M., Horst, R.L., 2003. Future directions in air quality research: Economic issues. Environment International 29: 289- 302.

[30] Adams, R.M., Glyer, J.D., McCarl, B.A., 1988. The NCLAN economic assessment: approach and findings and implications. In: Heck, W.W., Taylor, O.C., Tingey, D.T. (eds), Assessment of crop loss from air pollutants. London, UK: Elsevier pp. 473- 504.

[31] Adams, R.M., Hamilton, S.A., Mc Carl, B.A., 1984. The economic effects of ozone on agriculture.Corvallis, Oregon: Environmental Research Laboratory, US Environmental Protection Agency.

Citation: SATESH KUMAR DEVRAJANI,et.al., " Impact of Gaseous Air Pollutants on Agricultural Crops in Developing Countries: A Review", International Journal of Research in Environmental Science (IJRES), vol. 6 , no. 2, pp.1-8, 2020. Available: DOI: http://dx.doi.org/10.20431/2454-9444.0602001

Copyright: (C) 2020 Authors. This is an open-access article distributed under the terms of the Creative Commons Attribution License, which permits unrestricted use, distribution, and reproduction in any medium, provided the original author and source are credited. 